\title{
PENGARUH LARUTAN BONGGOL NANAS (Ananas comosus L.Merr) DAN DAUN SIRIH (Piper betle L.) DALAM MENURUNKAN JUMLAH KUMAN PADA PERALATAN MAKAN BAKSO GEROBAK WAHYUNI SAHANI ${ }^{1}$ dan BESSE INDRAYANTI ${ }^{2}$ \\ ${ }^{1.2}$ Poltekkes Kemenkes Makassar \\ indrayanti18.iy@gmail.com
}

\begin{abstract}
In Indonesia, street vendors do not pay attention to the cleanliness of tableware used so it can cause various dangers such as diseases then it is necessary to handle the handling of tableware that is by utilizing pineapple knobs and betel leaf as a disinfectant material. This study aims to determine the effect of pineapple's leaf solution and betel's leaf in reducing the amount of germs in the wagon's meatballs. The research type is experiment with quasi experiment approach, that is test by comparing result with control. Laboratory analysis by Total Plate Count Method (ALT). Processing and presentation of data in the form of tables. Data were analyzed by Independent Sample T-Test. The results showed that the solution of pineapple's leaf and betel's leaf at $5 \%$ concentration can decrease the number of germs in the tableware with the percentage decrease as much as $42 \%$. While percentage decrease at $10 \%$ concentration is as much as $71 \%$. And the result of statistic test show that the sig value $(0,033)<\alpha$ $(0,05)$ eat there is difference of decrease between concentration $5 \%$ with concentration $10 \%$. Conclusion in this research is solution of pineapple's leaf and betel leaf concentration $10 \%$ more effective decrease amount of germ at tableware compared to $5 \%$ concentration. As a suggestion to the next researcher, it is advisable to increase the concentration of the solution and do move variations of times leaf with the tableware so that the decrease in the number of germs can meet the requirements.

Keywords: Number of Germs, Tableware, Pineapples, Betel Leaf
\end{abstract}

\section{ABSTRAK}

Di Indonesia, pedagang kaki lima tidak memperhatikan kebersihan peralatan makan yang digunakan sehingga dapat menyebabkan berbagai bahaya seperti penyakit maka dari itu diperlukan penanganan untuk mendesinfektasi peralatan makan yaitu dengan memanfaatkan bonggol nanas dan daun sirih sebagai bahan desinfektan. Penelitian ini bertujuan untuk mengetahui pengaruh larutan bonggol nanas dan daun sirih dalam menurunkan jumlah kuman pada peralatan makan bakso gerobak. Jenis penelitian adalah eksperimen dengan pendekatan quasi eksperimen, yaitu pengujian dengan membandingkan hasil dengan kontrol. Analisa laboratorium dengan metode Angka Lempeng Total (ALT). Pengolahan dan penyajian data dalam bentuk tabel dan diagram. Data dianalisis dengan uji Independent Sample T-Test. Hasil penelitian menunjukkan bahwa larutan bonggol nanas dan daun sirih pada konsentrasi $5 \%$ dapat menurunkan jumlah kuman pada alat makan dengan persentase penurunan sebanyak $42 \%$. Sedangkan persentase penurunan pada konsentrasi $10 \%$ adalah sebanyak $71 \%$. Dan hasil uji statistik menunjukkan bahwa nilai sig $(0,033)<\alpha(0,05)$ makan ada perbedaan penurunan antara konsentrasi $5 \%$ dengan konsentrasi $10 \%$. Kesimpulan dalam penelitian ini adalah larutan bonggol nanas dan daun sirih konsentrasi $10 \%$ lebih efektif menurunkan jumlah kuman pada alat makan dibandingkan konsentrasi $5 \%$. Sebagai saran kepada peneliti selanjutnya, sebaiknya dilakukan peningkatan konsentrasi larutan dan melakukan variasi waktu kontak larutan dengan peralatan makan lebih lama sehingga penurunan jumlah kuman dapat memenuhi persyaratan.

Kata Kunci : Jumlah Kuman, Alat Makan, Bonggol Nanas, Daun Sirih

\section{PENDAHULUAN}

Di Indonesia, pedagang kaki lima yang biasanya menjalankan usahanya dengan menggunakan fasilitas-fasilitas umum, seperti trotoar, pinggir-pinggir jalan umum, pasar dan lain sebagainya semakin banyak ditemukan. Namun keadaan ini dapat menyebabkan berbagai bahaya seperti penyakit akibat pedagang tidak memperhatikan kebersihan lokasi penjualan makanan.

Telah diketahui tentang faktor-faktor yang menunjang terjadinya penyakit asal makanan yaitu diantaranya makanan yang kurang matang memasaknya, penyimpanan makanan pada suhu yang tidak sesuai, makanan yang diperoleh dari sumber yang kurang bersih, peralatan yang tercemar, kesehatan pribadi yang kurang baik, dan cara pengawetan yang kurang sempurna sehingga faktor-faktor tersebut perlu diperhatikan dalam hal pengolahan makanan.
Salah satu faktor yang menunjang terjadinya penyakit asal makanan yaitu peralatan yang tercemar. Kebersihan peralatan makanan yang kurang baik akan mempunyai peranan penting dalam pertumbuhan dan perkembangbiakan kuman, penyebaran penyakit dan kejadian luar biasa (KLB) keracunan, untuk itu peralatan makanan perlu dijaga terus tingkat kebersihannya supaya terhindar dari kontaminasi kuman patogen serta cemaran zat lainnya.

Oleh karena itu diperlukan penanganan untuk membebashamakan peralatan makan yaitu dengan memanfaatkan bonggol nanas dan daun sirih sebagai bahan desinfektan karena kedua tanaman ini bersifat desifektan. Nanas mempunyai kandungan zat yang sangat kompleks, karena mengandung beberapa bahan kimia, seperti klor, iodium, dan fenol yang berfungsi sebagai desinfektan. Nanas mempunyai kandungan enzim bromelin yang dapat mencerna protein sebesar 1.000 kali beratnya, sehingga nanas bermanfaat 
sebagai penghancur lemak. Hasil konsumsi dan olahan nanas akan menghasilkan limbah berupa kulit dan bonggol nanas dalam jumlah banyak. Limbah tersebut hanya dibuang begitu saja sehingga perlu untuk dimanfaatkan agar limbah yang terbuang dapat bernilai ekonomis. Sedangkan daun sirih mengandung kavikol dan blethephenol yang terkandung dalam minyak atsiri. Kavikol inilah yang memberikan bau khas daun sirih dan memiliki daya pembunuh bakteri lima kali lipat dari phenol biasa (Moeljanti, 2003) sehingga baik digunakan sebagai desinfektan.

\section{BAHAN DAN METODE}

\section{Lokasi Penelitian}

Penelitian ini dilakukan di pasar tradisional kota Makassar, yaitu pasar Butung dan pasar Terong. Untuk pemeriksaan jumlah kuman pada alat makan dilakukan di laboratorium Politeknik Kesehatan Makassar Jurusan Kesehatan Lingkungan.

2. Desain dan Variabel Penelitian

Adapun jenis penelitian ini adalah jenis penelitian eksperimen dengan pendekatan quasi eksperimen yaitu perlakuan uji kemampuan larutan bonggol nanas (Ananas comosus L.Merr) dan Daun Sirih (Piper betle L.) konsentrasi $5 \%$ dan $10 \%$ dalam menurunkan jumlah kuman pada alat makan bakso gerobak.

Variabel dalam penelitian ini adalah kemampuan larutan bonggol nanas (Ananas comosus L.Merr) dan Daun Sirih (Piper betle L.) konsentrasi $5 \%$ dan $10 \%$ dalam menurunkan jumlah kuman pada alat makan bakso gerobak.

3. Sampel

Sampel dalam penelitian ini adalah sampel alat makan mangkok, sendok, dan garpu yang diambil dari penjual bakso gerobak di pasar Butung dan di pasar Terong dengan jumlah sampel sebanyak 27 sampel.

\section{Pengumpulan Data}

a. Data Primer

Data primer diperoleh melalui pemeriksaan jumlah kuman sebelum dan sesudah perlakuan di laboratorium.

b. Data Sekunder

Data sekunder diperoleh melalui penelusuran kepustakaan berupa referensi hasil penelitian sebelumnya, jurnal, artikel, maupun laporan pemerintah yang terkait seperti
Perusahaan Daerah Pasar Makassar Raya.

\section{Analisis Data}

Data yang telah diolah dianalisa dengan uji Independent Sampel T-Test dengan menggunakan program komputer SPSS untuk mengetahui besarnya perbedaan penurunan jumlah kuman pada alat makan setelah dilakukan perlakuan dengan menggunakan larutan bonggol nanas dan daun sirih.

\section{Hasil Penelitian}

Berdasarkan hasil pemeriksaan di laboratorium, jumlah kuman pada alat makan yang dicuci dengan larutan bonggol nanas dan daun sirih dengan konsentrasi $5 \%$ dan $10 \%$ terjadi penurunan jumlah kuman setelah perendaman selama 2 menit. Hasil pemeriksaan jumlah kuman peralatan makan pedagang bakso gerobak tanpa perlakuan (awal) dan dengan perlakuan larutan bonggol nanas dan daun sirih $5 \%$ dan $10 \%$ dapat dilihat pada tabel berikut ini:

\section{Tabel 1}

Persentase Penurunan Jumlah Kuman pada Peralatan Makan Pedagang Bakso Gerobak Dengan Perlakuan Larutan Bonggol Nanas dan Daun Sirih Konsentrasi $5 \%$

\begin{tabular}{|c|c|c|c|}
\hline \multirow{2}{*}{$\begin{array}{l}\text { Jenis } \\
\text { Alat } \\
\text { Makan }\end{array}$} & \multicolumn{2}{|c|}{ Jenis Perlakuan } & \multirow{2}{*}{$\begin{array}{c}\text { Persentase } \\
\text { Penurunan } \\
\text { (\%) }\end{array}$} \\
\hline & $\begin{array}{c}\text { Tanpa } \\
\text { Perlakuan }\end{array}$ & $\begin{array}{c}\text { Larutan } 5 \\
\%\end{array}$ & \\
\hline Mangkok & $\begin{array}{c}26 \\
\text { koloni/cm }\end{array}$ & $\begin{array}{c}11 \\
\text { koloni/cm }\end{array}$ & 63 \\
\hline Sendok & 350 koloni & 300 koloni & 15 \\
\hline Garpu & Rata - Rata & 230 koloni & $\begin{array}{l}48 \\
42\end{array}$ \\
\hline
\end{tabular}

Tabel 2

Persentase Penurunan Jumlah Kuman pada Peralatan Makan Pedagang Bakso Gerobak Dengan Perlakuan Larutan Bonggol Nanas dan Daun Sirih Konsentrasi $10 \%$

\begin{tabular}{|c|c|c|c|}
\hline \multirow{2}{*}{$\begin{array}{l}\text { Jenis } \\
\text { Alat } \\
\text { Makan }\end{array}$} & \multicolumn{2}{|c|}{ Jenis Perlakuan } & \multirow{2}{*}{$\begin{array}{c}\text { Persenta } \\
\text { se } \\
\text { Penuruna } \\
\text { n (\%) } \\
\end{array}$} \\
\hline & $\begin{array}{l}\text { Tanpa } \\
\text { Perlakuan }\end{array}$ & $\begin{array}{c}\text { Larutan } \\
10 \%\end{array}$ & \\
\hline Mangkok & $\begin{array}{c}26 \\
\text { koloni//cm }\end{array}$ & $\begin{array}{c}6 \\
\text { koloni/cm }\end{array}$ & 78 \\
\hline $\begin{array}{c}\text { Sendok } \\
\text { Garpu }\end{array}$ & $\begin{array}{l}350 \text { koloni } \\
472 \text { koloni } \\
\text { Rata - Rata }\end{array}$ & $\begin{array}{l}102 \text { koloni } \\
159 \text { koloni }\end{array}$ & $\begin{array}{l}70 \\
66 \\
71\end{array}$ \\
\hline
\end{tabular}


Jurnal Sulolipu : Media Komunikasi Sivitas Akademika dan Masyarakat

Vol. 18 No 22018

e-issn : 2622-6960, p-issn : 0854-624X

\begin{tabular}{ccc}
\hline \multicolumn{3}{c}{ Tabel 3} \\
Hasil Pemeriksaan Kualitas Bakteri \\
$\begin{array}{c}\text { Coliform Pada Air yang Digunakan Oleh } \\
\text { Pedagang Bakso Gerobak }\end{array}$ \\
\hline Sampel & $\begin{array}{c}\text { Hasil (CFU/100 } \\
\text { mI) }\end{array}$ & Ket \\
\hline $\begin{array}{c}\text { Air Sumur Bor } \\
\text { Pasar Terong }\end{array}$ & 75 & TMS \\
$\begin{array}{c}\text { Air Sumur Bor } \\
\text { Pasar Butung }\end{array}$ & 120 & TMS \\
$\begin{array}{c}\text { Air Sumur Bor } \\
\text { Pasar Butung }\end{array}$ & 120 & TMS \\
\hline
\end{tabular}

Tabel diatas menunjukkan hasil pemeriksaan kualitas air yang digunakan oleh pedagang bakso gerobak untuk mencuci alat makannya. Pada hasil tersebut dapat diketahui bahwa kandungan bakteriologis tertinggi yaitu pada air yang digunakan oleh pedagang 2 dan pedagang 3 dengan jumlah kuman sebanyak 120 CFU/100 ml. Berdasarkan Permenkes Nomor 32 tahun 2017, jumlah kuman pada air bersih yang dipersyaratkan adalah $50 \mathrm{CFU} / 100 \mathrm{ml}$, sehingga ketiga sampel tersebut diatas tidak memenuhi persyaratan.

\begin{tabular}{ccc}
\multicolumn{3}{c}{ Tabel 4} \\
Hasil Uji Statistik \\
\hline $\begin{array}{c}\text { Larutan Bonggol } \\
\text { Nanas dan Daun } \\
\text { Sirih }\end{array}$ & Mean & $\begin{array}{c}\text { Sig. (2- } \\
\text { tailed) }\end{array}$ \\
\hline $\begin{array}{c}\text { Konsentrasi 5 \% } \\
\text { Konsentrasi 10\% }\end{array}$ & 125,78 &, 033 \\
\hline
\end{tabular}

Pada tabel 4 menunjukkan mean atau ratarata penurunan tiap konsentrasi, yaitu pada konsentrasi $5 \%$ rata - rata penurunan yaitu 125,78 sedangkan pada konsentrasi $10 \%$ lebih tinggi yaitu dengan rata - rata penurunan 210,89 . Selanjutnya pada kolom sig yaitu output untuk mengetahui apakah kedua konsentrasi larutan bonggol nanas dan daun sirih memiliki penurunan yang sama. Dan berdasarkan hasil yang diperoleh yaitu nilai sig $=$ 0,033 . Hal ini berarti sig $(0,033)<\alpha(0,05)$, maka $\mathrm{H}_{0}$ ditolak. Jadi, dengan signifikasi $5 \%$ didapatkan kesimpulan bahwa konsentrasi $5 \%$ dan konsentrasi $10 \%$ memiliki penurunan jumlah yang tidak sama atau ada perbedaan.

\section{PEMBAHASAN}

Dalam pembahasan ini penulis akan menguraikan analisa hasil penelitian sebagai berikut:
1. Kemampuan larutan bonggol nanas dan daun sirih konsentrasi $5 \%$ dalam menurunkan jumlah kuman pada peralatan makan bakso gerobak

Hasil pemeriksaan yang diperoleh untuk keseluruhan penurunan jumlah kuman pada alat makan dengan konsentrasi $5 \%$ adalah sebanyak $42 \%$ penurunannya. Hal ini menandakan bahwa larutan bonggol nanas dan daun sirih konsentrasi $5 \%$ belum terlalu efektif dalam jumlah penurunannya. Untuk hasil jumlah kuman setelah pencucian, belum memenuhi persyaratan berdasarkan Permenkes Nomor 1096 Tahun 2011 tentang Higiene Sanitasi Jasaboga bahwa jumlah kuman pada peralatan makan harus $0 \mathrm{koloni} / \mathrm{cm}^{2}$. Dapat dilihat pada tabel 5.1, jumlah kuman setelah pencucian belum ada yang mencapai penurunan hingga 0 koloni/ $\mathrm{cm}^{2}$.

Bonggol nanas dan daun sirih memiliki sifat bactericida karena adanya kandungan klor dan fenol pada bonggol nanas serta kavikol dan minyak atsiri pada daun sirih. Namun, kandungan klor dan fenol dalam bonggol nanas khasiatnya dapat menurun dengan adanya zat organik (Rahardja, 2007), sehingga hanya sebagian jumlah kuman yang dapat diturunkan. Penambahan jumlah konsentrasi larutan bonggol nanas dan daun sirih yang lebih tinggi dapat memperoleh hasil yang lebih efektif dalam menurunkan jumlah kuman (llyas, 2005) karena pengaruh desinfektan pada bonggol nanas dan daun sirih yang semakin tinggi.

Banyak faktor yang dapat mempengaruhi efektivitas suatu desinfektan, diantaranya tinggi rendahnya konsentrasi, lama kerjanya/paparan, suhu, jenis dan jumlah mikroorganisme hadir, zat pelarut dan terdapatnya bahan pengganggu yang dapat menurunkan efektivitas desinfektan adalah senyawa organik.

Penelitian yang sejalan yaitu oleh Anggraini (2012), tentang formulasi sabun cair dari ekstrak batang nanas untuk mengatasi jamur Candida albicans menunjukkan konsentrasi ekstrak batang nanas $7 \%$ mampu menghambat pertumbuhan jamur Candida albicans. Ekstrak batang nanas $7 \%$ memiliki aktifitas anti jamur yang cukup kuat dengan diameter daerah hambat 21,3 $\mathrm{mm}$.

Menurut Nugraheni (2016), enzim bromelin banyak terdapat di batang dan bagian tengah buah nanas. Nanas mempunyai kandungan enzim bromelin sama dengan papain pada pepaya yang dapat mencerna protein sebesar 1000 kali beratnya. Sehigga nanas bermanfaat 
sebagai penghancur lemak. Enzim bromelin dapat mengencerkan lendir, sehingga dapat membersihkan sisa makanan pada peralatan makan yang berlendir disertai lengket seperti minyak dan lemak pada piring yang memungkinkan membawa bakteri.

2. Kemampuan larutan bonggol nanas dan daun sirih konsentrasi $10 \%$ dalam menurunkan jumlah kuman pada peralatan makan bakso gerobak

Hasil pemeriksaan yang diperoleh untuk keseluruhan penurunan jumlah kuman pada alat makan dengan konsentrasi $10 \%$ adalah sebanyak $71 \%$ penurunannya. Hal ini menandakan bahwa larutan bonggol nanas dan daun sirih konsentrasi $10 \%$ lebih efektif dalam jumlah penurunannya jika dibandingkan dengan konsentrasi $5 \%$. Untuk hasil jumlah kuman setelah pencucian, belum memenuhi persyaratan berdasarkan Permenkes Nomor 1096 Tahun 2011 tentang Higiene Sanitasi Jasaboga bahwa jumlah kuman pada peralatan makan harus $0 \mathrm{koloni} / \mathrm{cm}^{2}$. Dapat dilihat pada tabel 5.1, jumlah kuman setelah pencucian belum ada yang mencapai penurunan hingga 0 koloni $/ \mathrm{cm}^{2}$.

Penelitian ini sejalan dengan penelitian Wachidin (2013), yang melakukan pembilasan alat makan dengan menggunakan ekstrak daun sirih dengan persentase penurunan sebanyak 70,19\% pada konsentrasi $15 \%$. Hal ini menandakan bahwa penggunaan larutan bonggol nanas dan daun sirih konsentrasi 10 $\%$ dalam pencucian alat makan efektif, karena mengingat kandungan bactericida dua kali lipat yang berasal dari bonggol nanas dan daun sirih.

Daun sirih merupakan salah satu jenis tanaman yang memiliki aroma dan rasa yang khas, sangat tajam dan merangsang disebabkan oleh kavikol dan blethephenol yang terkandung dalam minyak atsiri. Kavikol inilah yang memberikan bau khas daun sirih dan memiliki daya pembunuh bakteri lima kali lipat dari phenol biasa (Moeljanto, 2003) sehingga baik digunakan sebagai desinfektan. Bau yang tajam dari daun sirih dapat dinetralisir oleh bonggol nanas yang memiliki aroma yang harum dibandingkan daun sirih. Bactericida dari bonggol nanas diperoleh dari kandungan enzim bromelin yang banyak terdapat di batang dan bagian tengah buah nanas. Nanas mempunyai kandungan enzim bromelin sama dengan papain pada pepaya yang dapat mencerna protein sebesar 1000 kali beratnya. Sehigga nanas bermanfaat sebagai penghancur lemak. Enzim bromelin dapat mengencerkan lendir, sehingga dapat membersihkan sisa makanan pada peralatan makan yang berlendir disertai lengket seperti minyak dan lemak pada piring yang memungkinkan membawa bakteri.

Oleh karena itu, penambahan konsentrasi larutan bonggol nanas dan daun sirih yang lebih tinggi dari $10 \%$ akan lebih efektif digunakan sebagai desinfektan atau waktu kontak larutan dengan alat makan dapat dinaikkan yaitu lebih lama dari 2 menit.

3. Perbedaan larutan bonggol nanas dan larutan bonggol nanas dan daun sirih konsentrasi $10 \%$ dalam menurunkan jumlah kuman pada peralatan makan bakso gerobak

Berdasarkan penelitian yang dilakukan dengan perbandingan konsentrasi $5 \%$ dan 10 $\%$ dapat diinterpretasikan bahwa semakin tinggi konsentrasi larutan bonggol nanas dan daun sirih yang digunakan maka akan semakin besar kemampuannya dalam menurunkan jumlah kuman pada peralatan makan. Dari hasil pemeriksaan kedua konsentrasi larutan bonggol nanas dan daun sirih yang mendekati standar adalah larutan dengan konsentrasi $10 \%$ sehingga dianggap lebih efektif dibandingkan larutan konsentrasi $5 \%$.

Hal ini sesuai dengan hasil uji statistik yang diperoleh yaitu nilai mean untuk kedua konsentrasi larutan mengalami perbedaan yang cukup jauh. Berdasarkan pemeriksaan yang telah dilakukan diketahui bahwa persentase penurunan untuk larutan konsentrasi $5 \%$ adalah sebanyak $42 \%$, sedangkan untuk larutan konsentrasi $10 \%$ memiliki selisih yang cukup jauh yaitu dengan persentase penurunan sebanyak $71 \%$. Hal ini sejalan dengan hasil uji statistik yaitu nilai signifikan dibawah dari nilai 0,05 sehingga dianggap ada perbedaan penurunan antara alat makan yang direndam menggunakan larutan bonggol nanas dan daun sirih konsentrasi $5 \%$ dengan larutan konsentrasi $10 \%$.

\section{KESIMPULAN DAN SARAN}

\section{Kesimpulan}

a. Pembilasan peralatan makan dengan larutan bonggol nanas dan daun sirih konsentrasi $5 \%$ mampu menurunkan jumlah kuman pada peralatan makan bakso gerobak hingga $42 \%$.

b. Pembilasan peralatan makan dengan larutan bonggol nanas dan daun sirih konsentrasi $10 \%$ mampu menurunkan 
Jurnal Sulolipu : Media Komunikasi Sivitas Akademika dan Masyarakat

Vol. 18 No 22018

e-issn : 2622-6960, p-issn : 0854-624X

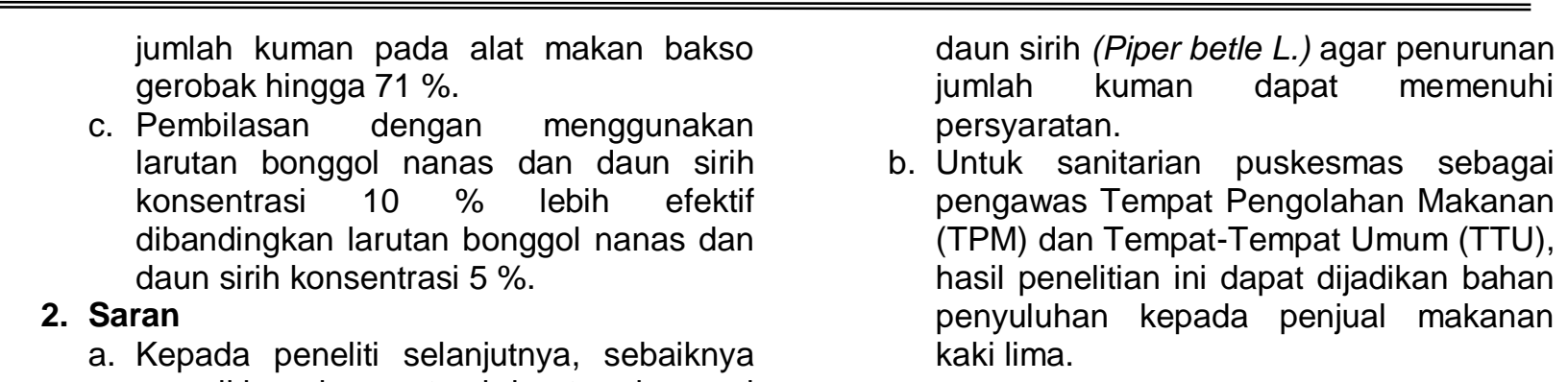
menaikkan konsentrasi larutan bonggol nanas (Ananas comosus L.Merr) dan

\section{DAFTAR PUSTAKA}

Anggraini, D., Rahmides, W.S., Malik, M. 2012. Formulasi Sabun Cair Ekst rak Batang Nanas Untuk Mengatasi Jamur. Jurnal Penelitian Farmasi Indonesia. 1 (1): 30-33. (Online) http://repository.unnes.ac.id Diakses 12 Desember 2017.

BPOM, 2016. Berita Keracunan. Jakarta : Kepala Badan Pengawas Obat dan Makanan.

Bagus, Setiawan. 2016. Daya Hambat Konsentrasi Enzim Bromelin Dari Ekstrak Bonggol Nanas (Ananas comosus (L.) Merr) Terhadap Streptococcus sanguinis. Makassar: Fakultas Kedokteran Gigi Universitas Hasanuddin. (Skripsi tidak diterbitkan).

Cecep, Sucipto Dani. 2015. Keamanan Pangan. Yogyakarta: Gosyen Publishing.

Dwivedi, V., Tripathi.S. 2014. Review Study On Potential Activity Of Piper betle. Journal of Pharmacognosy and Phytochemistry, 3 (4): 93-98. (Online) http://repository.uajy.ac.id Diakses 20 Desember 2017.

Haderiah., Sulasmi., dan Novi. 2015. Studi Kualitas Bakteriologis Peralatan Makan Pada Rumah Makan di Kota Makassar. Jurnal Hygiene. 1 (2): 126-127.

Ilyas, Muhammad. 2005. Daya Hambat Minimal Ekstrak Bonggol Nanas terhadap Pertumbuhan Gram Positif Dalam Plak Gigi. Jurnal PDGI. 1 (2): 193-197. (Online) http://repository.unnes.ac.id Diakses 7 Desember 2017.

Irianto, Koes. 2006. Mikrobiologi Menguak Dunia Mikroorganisme. Bandung: Yrama Widya.

Moeljanto dan Mulyono. 2003. Khasiat Dan Manfaat Daun Sirih, dalam Jurnal Ekstrak Daun Sirih (Piper betle L.) Pada Proses Pembilasan Alat Makan Terhadap Jumlah Angka Kuman. Jurnal Mitra Raflesia. 5 (2) : 2. (Online) http://repository.unnes.ac.id Diakses 10 Desember 2017.

Nugrahaeni. 2016. Sehat Tanpa Obat Dengan Nanas. Yogyakarta: Rapha Publishing.

Rahardja. 2007. Obat-Obat Penting, Khasiat, Penggunaan dan Efel-Efek Sampingnya. Jakarta: PT Elex Media Komputindo Kelompok Gramedia.

Rahmat, Reski Andi. 2014. Kemampuan Larutan Bonggol Nanas (Ananas comosus L.Merr) Dalam Menurunkan Jumlah Kuman Pada Peralatan Makan Penjual Makanan. Makassar: Fakultas Kesehatan Masyarakat Universitas Hasanuddin. (Skripsi tidak diterbitkan)

Republik Indonesia. 2010. Peraturan Menteri Kesehatan RI Nomor 492 tentang Persyaratan Kualitas Air Minum.

Republik Indonesia. 2011. Peraturan Menteri Kesehatan RI Nomor 1096 tentang Higiene Sanitasi Jasaboga.

Republik Indonesia. 2012. Peraturan Menteri Kesehatan RI Nomor 18 tentang Pangan.

Republik Indonesia. 2012. Peraturan Presiden Republik Indonesia Nomor 125 tentang Koordinasi Penataan Dan Pemberdayaan Pedagang Kaki Lima.

Sasmito, Ediati. 2017. Imunomodulator Bahan Alami. Yogyakarta: Rapha Publishing.

Soedarya, Arief Prahasta. 2009. Budidaya Usaha Pengolahan Agribisnis Nanas. Bandung: Pustaka Grafika.

Sugiharsono. 2000. Ekonomi. Jakarta: Grafindo Media Pertama.

Sri, Yuliani., dan Satuhu, Suyanti. 2012. Panduan Lengkap Minyak Atsiri. Jakarta: Penebar Swadaya. 
Jurnal Sulolipu : Media Komunikasi Sivitas Akademika dan Masyarakat

Vol. 18 No 22018

e-issn : 2622-6960, p-issn : 0854-624X

Wachidin, Gamaiwarivoni. 2013. Ekstrak Daun Sirih (Piper betle L.) Pada Proses Pembilasan Alat Makan Terhadap Jumlah Angka Kuman. Jurnal Mitra Raflesia. 5 (2) : 2. (Online) http://repository.ui.ac.id Diakses 28 Desember 2017.

Zaenab, dkk. 2016. Buku Panduan Praktikum PMM-A. Makassar: Poltekkes Kemenkes Makassar Jurusan Kesehatan Lingkungan. 